\title{
Differential Effects of Mycorrhizal Fungi and Phosphate Solubilizing Bacteria and Their Potential for Stimulating Plant Growth and Seed Yield of Common Bean
}

\author{
Elkhatib, H.A. ${ }^{1}$ S.M. Gabr, ${ }^{1}$ F.I.Radwan ${ }^{2}$ and R.F. Abo El-Ali ${ }^{3}$
}

\begin{abstract}
Two field experiments were conducted at the Experimental Farm of Faculty of agriculture Damanhour Branch, Alexandria University at El-Bostan region to evaluate the effects of phosphorous solubilizing bacteria( PDB) (Bacillus megaterium as a commercial product Phosphorein), and Vesicular Arbuscular Mycorrhiza (Glomus macrocarpium) with four different fertilization levels of inorganic phosphorus $\left(0,30,60\right.$ and $90 \mathrm{~kg} \mathrm{P}_{2} \mathrm{O}_{5}$ fed. $^{-1}$ ) on the growth, seed yield, seed protein, $\mathrm{N}, \mathrm{P}$ and $\mathrm{K}$ contents of seeds of common bean (Phaseolus vulgaris $\mathrm{L}_{\text {.) }}$ cv."Bronco". The results revealed that Inoculation of common bean seeds with Mycorrhiza gave significantly higher mean values of dry seed yield fed. ${ }^{-1}$ than those inoculated with Phosphorein in both seasons also the inoculation of common bean seeds with Mycorrhiza or Phosphorein and application of 60 or $90 \mathrm{~kg} \mathrm{P}_{2} \mathrm{O}_{5}$ fed $^{-1}$. was the best combined treatment Moreover, inoculation with VAM or PDB under the applied P-mineral levels supply reflected significant difference on the percentage of $N, P$ and protein content in dry seeds in both seasons.

Polynomial quadratic models were established and used to describe seed yield responses of bean plants inoculated with Phosphorein or Mycorrhiza in combination with four different levels of P-mineral. The equation constants were used to calculate maximum rates of $P$ fertilizer $\left(P_{\max }\right)$ and the corresponding maximum yields $\left(Y_{\max }\right.$. ) for all treatments.
\end{abstract}

Keywords: common bean, polynomial quadratic equation, Mycorrhiza, phosphorous solubilizing bacteria, phosphorous.

\section{INTRODUCTION}

It has been reported that the P-solubilizing microorganisms are able to solubilize the unavailable forms of $\mathrm{P}$ in soil because they can excrete organic acids, which can strongly increase phosphorous concentrations by mechanisms involve chelating and exchange reactions in the soil environment (Maliha et al., 2004). The beneficial effects of PSM on legumes have been reported (Zaidi et al. 2004); PS bacteria solubilize the insoluble $\mathrm{P}$ and make it available to the crops (Gupta, 2004). In addition, the PS bacteria also release growth-promoting substances (Sattar and Gaur, 1987) that augment crop productivity. Therefore, for agronomic utility, the inoculation of the plants with rhizospheric microorganisms is necessary to take advantage of their beneficial properties for yield enhancement. On the other hand arbuscular mycorrhizal fungus (AMF) benefit their host principally by increasing uptake of relatively immobile phosphate, due to the ability of the fungal mycelium to grow beyond the phosphate depletion zone that quickly develops around the root (Smith and Read, 1997, AMF may also enhance plant uptake of macronutrients other than $\mathrm{P}$, including nitrogen, potassium and magnesium (Smith and Read, 1997).

Common bean is the most important legume worldwide for direct human consumption. Nutritionists characterize the common bean as a nearly perfect food because it represents an inexpensive source of protein and micronutrients to low-income consumers. Beans provide needed calories (up to $30 \%$ of the dietary energy), folic acid (vitamin B), dietary fiber, essential inorganic micronutrients ( $\mathrm{Fe}, \mathrm{Zn}, \mathrm{Ca}, \mathrm{Mg}$, and $\mathrm{Cu}$ ), flavones, antioxidants, and anticarcinogenic compounds (Bennink, 2001). In recent years, there is increasing interest in organic food production that limit the use of chemicals in agriculture, especially for fresh vegetable exported to Europe. However, studies are limited regarding use of biofertilizers in common bean under Egyptian conditions.

Therefore, it is of great practical importance to evaluate the effect of PS bacterium (Bacillus megaterium) and AM fungus (Glomus macrocarpium) and their specific role on plant growth and seed yield. The objective of the present work was to evaluate the efficiency of Bacillus megaterium and AM on the growth, seed yield and $\mathrm{N}$ and $\mathrm{P}$ uptake by bean plants.

\section{MATERIALS AND METHODS}

Two field experiments were carried out at Experimental Farm of Faculty of agriculture Damanhour Branch, Alexandria University at El-Bostan region. The soil was cultivated with bean plants (Phaseolus vulgaris L.)during the growing seasons of 2004and 2005.

\footnotetext{
${ }^{1}$ Horticulture Dept.Faculty of Agriculture,Damanhour Branch Alex. Univ.

${ }^{2}$ Agronomy Dept. Faculty of Agriculture, saba Basha, Alex. Univ.

${ }^{3}$ Agricultural research center, Alex.

Received March 3, 2009, Accepted March 31, 2009
} 


\section{Experimental Layout:}

Both experiments were designed as a factorial in a complete randomized blocks design of eight treatments), with four replicates for each main treatment. $\mathrm{P}$ mineral fertilizer was added at rates 0,30 , 60 and $90 \mathrm{~kg} \mathrm{P}_{2} \mathrm{O}_{\mathrm{s}} /$ fed for with the combination of two biofertilizers types (Phosphorein and Mycorrhiza). Phosphorus was applied in the form of super-phosphate $\left(15.5 \% \mathrm{P}_{2} 0_{\mathrm{S}}\right)$ which added during soil preparation. $\mathrm{N}$ mineral fertilizer at a rate $60 \mathrm{~kg} \mathrm{~N} / \mathrm{fed}$ in the form of ammonium sulphate $(20.5 \% \mathrm{~N})$ and K-mineral fertilizer at a rate $48 \mathrm{~kg} \mathrm{~K}_{2} 0 / \mathrm{fed}$ in the form of potassium sulphate $\left(48 \% \mathrm{~K}_{2} 0\right)$ were added in three equal doses after 2,4 and 6 weeks after sowing. Each experimental plot area was $15 \mathrm{~m}^{2}$ and contained 5 ridges; length and 0.6 width and each two adjacent experimental units were separated by a guard row. Bean seeds were inoculated and sowed on one side of the row at $15 \mathrm{~cm}$ apart on 6th and 9th of September in 2004 and 2005 seasons respectively.

\section{Inocula used:}

It was represented by a mixture of Vesicular Arbuscular Mycorrhizal (VAM) inoculum in the form of Glomus macrocarpium. This inoculum supplied by the Biofertilizer Unit, Faculty of Agriculture, Saba Basha Branch, Alexandria University. The mycorrhizal inoculum consisted of infected root fragments, spores and mycelium. Ten grams of mycorrhizal inoculums consisted of infected root fragments, spores and mycelium contained 25 spores $\mathrm{g}^{-1}$ was added into each planting hole at sowing time. Inoculum of Phosphate Dissolving Bacteria (PDB) was used from a commercial product of Agriculture Research Center and called Phosphorin contains active bacteria (Bacillus megaterium). The inoculation was performed by coating the seeds at the rate of $40 \mathrm{gms} / \mathrm{kg}$ of seeds using staking substance (Arabic gum 5\%) just before sowing.

Soil analysis. Soil surface samples $(0-25 \mathrm{~cm})$ were taken, then air dried, ground, sieved through a $2 \mathrm{~mm}$ sieve and then subjected to determine some soil chemical and physical properties by the method of Page et al. (1982) (Table 1).

The dry pods of 10 randomly selected plants, in each treatment, were picked to measure the following data: Number of dry pods plant ${ }^{-1}$, Weight of dry seeds $\operatorname{pod}^{-1}$, dry seeds yield feddan ${ }^{-1}$ : Seed index (weight of 100 seeds). Wet digestion procedure was performed on seeds according to Chapman and Pratt (1978) and the following determinations were carried out in the digested solution: Total Phosphorus and Potassium were determined as reported by Jackson (1967).Total Nitrogen was determined using micro- kjeldahl method according to Ling (1963).The total protein content was calculated by multiplying of the total $\mathrm{N}$ in seeds by a factor of 6.25 .

All obtained data were statistically analyzed using SAS software program (1996). Comparisons among the means of different treatments were conducted using the Least Significant Difference Procedure at $\mathrm{P}=0.05$ level as illustrated by Snedecor and Cochran (1989).

Table1. The main physical and chemical properties of the soil of the experimental sites during 2004 and 2005 seasons

\begin{tabular}{lcc}
\hline Parameters & \multicolumn{2}{c}{ Seasons } \\
\cline { 2 - 3 } & $\mathbf{2 0 0 4}$ & $\mathbf{2 0 0 5}$ \\
\hline Physical properties & & \\
Clay\% & 8.00 & 8.00 \\
Silt\% & 4.00 & 4.00 \\
Sand\% & 88.00 & 88.00 \\
Soil texture & sand & sand \\
Chemical properties & & \\
PH & 8.00 & 8.13 \\
EC(dsm & \\
Caco & & \\
Macro-elements (ppm) & 1.20 & 1.17 \\
$\mathrm{~N}$ & 2.10 & 2.04 \\
$\mathrm{P}$ & & \\
$\mathrm{K}$ & 20.00 & 23.00 \\
& 18.00 & 23.00 \\
& 184.00 & 176.00 \\
\hline
\end{tabular}

\section{RESULTS AND DISCUSSIONS}

\section{Effects of The Biofertilizer Types on Vegetative Growth Characters :}

Data presented in Table (2) indicated that inoculation of common bean seeds either with Phosphorein or Mycorrhiza did not detect any significant difference between them on leaves, stem and plant dry weight. Similar results were reported by ELkorashy (2003 ) on peanut Plants reported that the inoculation of Mycorrhiza was responsible for significant increments on dry weight plant $^{-1}$ and dry matter \% compared with the uninoculated plants.

\section{Effect of Phosphorus Fertilizer on Vegetative Growth Characters:}

Table (2), showed that the application of 30, 60 and $90 \mathrm{Kg} \mathrm{P}_{2} \mathrm{O}_{5} \mathrm{fed}^{-1}$ to the growing plants, significantly increased leaves, stem and plant dry weight over the control treatment, in both seasons. The percentages of the increases of plant dry weight were $56.80 \%, 83.03 \%$ and $79.65 \%$ in fall season of 2004 and $47.74 \%, 75.79$ $\%$ and $67.44 \%$ in fall season of 2005 as a result of using 30, 60 and $90 \mathrm{~kg} \mathrm{P}_{2} \mathrm{O}_{5}$ fed $^{-1}$ respectively. Also the comparisons among the mean values of each growth character indicated that, whether $\mathrm{P}$ application rate was 60 or $90 \mathrm{P}_{2} \mathrm{O}_{5} \mathrm{fed}^{-1}$, the studied vegetative growth 
characters were the best. Moreover, the difference

between these two $\mathrm{P}$ levels was not significant on all

Table 2. The main effects of biofertilizer types and phosphorus fertilizer rates on the vegetative growth characters of common bean plants during the seasons of 2004 and 2005

\begin{tabular}{|c|c|c|c|c|c|c|}
\hline \multirow[t]{2}{*}{ Treatments } & \multicolumn{2}{|c|}{ Leaves dry weight (g) } & \multicolumn{2}{|c|}{ Stem dry weight (g) } & \multicolumn{2}{|c|}{ Plant dry weight (g) } \\
\hline & 2004 & 2005 & 2004 & 2005 & 2004 & 2005 \\
\hline \multicolumn{7}{|l|}{ Biofertilizer type } \\
\hline Phosphorin & $7.19 \mathrm{a}$ & $7.76 \mathrm{a}$ & $6.07 \mathrm{a}$ & $6.54 \mathrm{a}$ & $13.84 \mathrm{a}$ & $14.95 \mathrm{a}$ \\
\hline Mycorrhiza & $7.56 \mathrm{a}$ & $8.21 \mathrm{a}$ & $6.38 \mathrm{a}$ & $6.80 \mathrm{a}$ & $14.62 \mathrm{a}$ & 15.81 \\
\hline \multicolumn{7}{|l|}{$\underline{P}$ rate $\left(\mathbf{k g ~ P}_{2} \mathbf{O}_{5}\right.$ fed $\left.^{-}\right)$} \\
\hline 0 & $4.83 \mathrm{c}$ & $5.49 \mathrm{c}$ & $3.81 \mathrm{~b}$ & $4.31 \mathrm{c}$ & $9.19 \mathrm{c}$ & $10.41 \mathrm{c}$ \\
\hline 30 & $7.35 \mathrm{~b}$ & $7.87 \mathrm{~b}$ & $6.53 \mathrm{a}$ & $6.75 \mathrm{~b}$ & $14.41 \mathrm{~b}$ & $15.38 \mathrm{~b}$ \\
\hline 60 & $7.35 \mathrm{~b}$ & $9.41 \mathrm{a}$ & $7.37 \mathrm{a}$ & $8.02 \mathrm{a}$ & $16.82 \mathrm{a}$ & 18.30 \\
\hline 90 & $8.68 \mathrm{a}$ & $9.16 \mathrm{a}$ & $7.19 \mathrm{a}$ & $7.60 \mathrm{ab}$ & $16.82 \mathrm{a}$ & $17.43 \mathrm{a}$ \\
\hline
\end{tabular}

*Values having a common alphabetical letter (s), do not significantly differ, using the revised L.S.D. test at $\mathrm{P}=0.05$

characters. The promoting effect of growth parameters could be attributed to phosphorous as a structural part of many compounds; nucleic acids, phospholipids, co enzymes NAD and NADP, ATP and other high energy compounds (Sarg, 2004). It is also a constituent of the cell nucleus and is essential for cell division and the development of meristematic tissues (Frank, 2002)) moreover, phosphorus is ubiquitous and essential element in the energy transfer processes. Similar results were reported by El - Kalla et al. (1997) on faba bean and onion, Feleafel And El-Araby (2001) found that the application of $\left(60 \mathrm{~kg} \mathrm{P}_{2} \mathrm{O}_{5} \mathrm{fed}^{-1}\right)$ to the common bean plants led to significant increments in average plant height, number of leaves and branches plant ${ }^{-1}$, fresh and dry masse plant $^{-1}$ and leaves area plant $^{-1}$ of common bean plants.,

\section{Interaction Effect of Phosphorous and Biofertilizers on Vegetative Growth Characters:}

Table (3) .showed that there were significant differences between biofertilizer types and phosphorous levels on leaves, stem and plant dry weight. The favoring effect of the inoculation with the biofertilizer types on vegetative growth characters, varied according to the used phosphours level. The combined treatments, which included inoculation with phosphorein or Mycorrhiza and 60or $90 \mathrm{~kg} \mathrm{P}_{2} \mathrm{O}_{5} \mathrm{fed}^{-1}$, was considered the best treatment, as it gave the highest mean value of all studied growth characters, in both seasons. The present results appeared to be in close agreements with the results reported by El - Shimi (2003)who found that application of $(100 \% \mathrm{P})$ gave the lowest value in leaf dry weight, application of (75\% P+ Phosphorein) or (50\%) $\mathrm{P}+$ Phosphorin) gave the highest parameters concerning leaf dry weight of sweet potato plants.

Effects of Phosphorein and Mycorrhiza on Dry Seeds Yield and Its Components:
The effects of biofertilizer inoculation on dry seeds yield fed. ${ }^{-1}$ was highly Significant in both seasons (Table 4). In contrast, no effects were found on number and weight of dry seeds pod $^{-1}$, seed index (100-seed weight) and number of pods plant $^{-1}$ in both seasons (Tables 2 and 3). The effect of AM fungi biofertilizer on dry seeds yield fed $^{-1}$ was superior and associated with the highest mean values of the dry seed yield characters comparing with Phosphorein. The fact that plant growth and yield increased in the presence of AM fungi suggested a strong synergistic relationship between root colonization, $\mathrm{P}$ uptake and growth promotion. In agreement with these findings Zaidi et al.(2003) observed that in low $\mathrm{P}$ soil plant growth and $\mathrm{P}$ uptake in chickpea were greater after inoculation with culture of AM fungi than after with phosphate dissolving bacteria.

\section{Effect of Phosphorus Fertilizer on Dry Seeds Yield} and its Components:

Tables 4 and 5 showed that the application of 60 and $90 \mathrm{Kg} \mathrm{P}_{2} \mathrm{O}_{5} \mathrm{fed}^{-1}$.significantly increased dry seeds yield fed $^{-1}$, number of dry pods plant ${ }^{-1}$, number of dry seeds $\operatorname{pod}^{-1}$, and seed index than the 0 and $30 \mathrm{Kg}$ $\mathrm{P}_{2} \mathrm{O}_{5} \mathrm{fed}^{-1}$ treatments, in both of $200^{\varepsilon}$ and $200^{\circ}$ seasons. Increasing $\mathrm{P}$ level from 0 to $60 \mathrm{~kg}_{2} \mathrm{O}_{5} \mathrm{fed}^{-1}$ resulted in pronounced increments on dry seeds yield fed ${ }^{-1}$; reached 174.96 and $157.02 \%$ in $200 \leqslant$ and $200^{\circ}$ seasons, respectively. Whereas, number of dry pods plant ${ }^{-1}$ were increased by 103.88 and $92.98 \%$ in 2004 and 2005 seasons, respectively. These data express that the application of 60 or $90 \mathrm{Kg} \mathrm{P}_{2} \mathrm{O}_{5}$ fed $^{-1}$ appeared to be sufficient for the plant to express their best performances on dry seeds yield and its components. El - Kalla et al. (1997) found that raising level of $\mathrm{P}_{2} \mathrm{O}_{5}$ to $45 \mathrm{~kg} \mathrm{P}_{2} \mathrm{O}_{5} \mathrm{fed}^{-1}$ increased faba bean number of pods plant $^{-1}$, number of seeds pod $^{-1}$, seed yield plant ${ }^{-1}$, seed index (100 seed weight) and dry seeds fed $^{-1}$.also Shafeek et al. (2004) found that the application of 
phosphorus fertilizer in the chemical form caused an increase in seed index, number of pods plant $^{-1}$ and or dry seeds pod $^{-1}$ as well as the average length and weight of pod of broad bean.

Table 3. The interaction effects of biofertilizer types and phosphours fertilizer rates on the vegetative growth characters of common bean plants during the seasons of 2004 and 2005

\begin{tabular}{|c|c|c|c|c|}
\hline \multirow[t]{3}{*}{$P$ rate $\left(\mathrm{kg} \mathrm{P}_{2} \mathrm{O}_{5}\right.$ fed $\left.^{-1}\right)$} & \multicolumn{2}{|c|}{2004} & \multicolumn{2}{|c|}{2005} \\
\hline & \multicolumn{4}{|c|}{ Leaves dry weight (g) } \\
\hline & Phosphorein & Mycorrhiza & Phosphorein & Mycorrhiza \\
\hline 0 & $4.62 \mathrm{c}^{*}$ & $5.32 \mathrm{c}$ & $5.05 \mathrm{bc}$ & $5.66 \mathrm{c}$ \\
\hline 30 & $7.35 \mathrm{ab}$ & $7.67 \mathrm{~b}$ & $7.35 \mathrm{ab}$ & $8.08 \mathrm{ab}$ \\
\hline 60 & $8.26 \mathrm{a}$ & $9.12 \mathrm{ab}$ & $9.04 \mathrm{a}$ & $9.70 \mathrm{a}$ \\
\hline \multirow[t]{2}{*}{90} & $8.55 \mathrm{a}$ & $8.93 \mathrm{ab}$ & $8.81 \mathrm{a}$ & $9.38 \mathrm{ab}$ \\
\hline & \multicolumn{4}{|c|}{ Stem dry weight (g) } \\
\hline & Phosphorein & Mycorrhiza & Phosphorein & Mycorrhiza \\
\hline 0 & $3.63 \mathrm{~b}$ & $4.18 \mathrm{c}$ & $3.98 \mathrm{~b}$ & $4.45 \mathrm{c}$ \\
\hline 30 & $6.62 \mathrm{a}$ & $6.88 \mathrm{~b}$ & $6.45 \mathrm{a}$ & $6.61 \mathrm{~b}$ \\
\hline 60 & $6.92 \mathrm{a}$ & $7.64 \mathrm{ab}$ & $7.81 \mathrm{a}$ & $8.39 \mathrm{a}$ \\
\hline \multirow[t]{3}{*}{90} & $7.11 \mathrm{a}$ & $7.44 \mathrm{ab}$ & $7.28 \mathrm{a}$ & $7.75 \mathrm{ab}$ \\
\hline & \multicolumn{4}{|c|}{ Plant dry weight (g) } \\
\hline & Phosphorein & Mycorrhiza & Phosphorein & Mycorrhiza \\
\hline 0 & $8.76 \mathrm{c}$ & $10.07 \mathrm{c}$ & $9.61 \mathrm{c}$ & $10.75 \mathrm{c}$ \\
\hline 30 & $14.55 \mathrm{ab}$ & $15.28 \mathrm{~b}$ & $14.28 \mathrm{~b}$ & $15.47 \mathrm{~b}$ \\
\hline 60 & $15.96 \mathrm{ab}$ & $17.62 \mathrm{a}$ & $17.68 \mathrm{a}$ & 18.99 a \\
\hline 90 & $16.09 \mathrm{ab}$ & $16.85 \mathrm{ab}$ & $16.92 \mathrm{ab}$ & $18.02 \mathrm{a}$ \\
\hline
\end{tabular}

*Values having a common alphabetical letter (s), do not significantly differ, using the revised L.S.D. test at $\mathrm{P}=0.05$.

Table 4. The main effects of biofertilizer types and phosphorus fertilizer rates on dry seed yield and its components of common bean during the seasons of 2004 and 2005

\begin{tabular}{|c|c|c|c|c|c|c|}
\hline \multirow[t]{2}{*}{ Treatments } & \multicolumn{2}{|c|}{ No. of dry seeds pod ${ }^{-1}$} & \multicolumn{2}{|c|}{$\begin{array}{c}\text { Weight of dry seeds pod } \\
\text { (g) }\end{array}$} & \multicolumn{2}{|c|}{ No. of dry pods plant $^{-1}$} \\
\hline & 2004 & 2005 & 2004 & 2005 & 2004 & 2005 \\
\hline \multicolumn{7}{|c|}{ Biofertilizer type } \\
\hline Phosphorin & $4.45 \mathrm{a}^{*}$ & $4.76 \mathrm{a}$ & $1.09 \mathrm{a}$ & $1.20 \mathrm{a}$ & $14.92 \mathrm{a}$ & $16.10 \mathrm{a}$ \\
\hline Mycorrhiza & $4.76 \mathrm{a}$ & $5.17 \mathrm{a}$ & $1.13 \mathrm{a}$ & $1.22 \mathrm{a}$ & $16.46 \mathrm{a}$ & $17.51 \mathrm{a}$ \\
\hline \multicolumn{7}{|c|}{$\left.\underline{P \text { rate }\left(\mathrm{kg} \mathrm{P}_{2}\right.} \underline{\mathrm{O}}_{5} \mathrm{fed}^{-1}\right)$} \\
\hline 0 & $3.70 \mathrm{c}$ & $4.12 \mathrm{c}$ & $0.89 \mathrm{~b}$ & $1.00 \mathrm{~b}$ & $9.27 \mathrm{c}$ & $10.40 \mathrm{~b}$ \\
\hline 30 & $4.57 \mathrm{~b}$ & $4.75 \mathrm{~b}$ & $1.14 \mathrm{a}$ & $1.20 \mathrm{~b}$ & $16.50 \mathrm{~b}$ & $17.57 \mathrm{a}$ \\
\hline 60 & $5.02 \mathrm{ab}$ & $5.57 \mathrm{a}$ & $1.21 \mathrm{a}$ & $1.34 \mathrm{a}$ & $18.90 \mathrm{a}$ & $20.07 \mathrm{a}$ \\
\hline 90 & $5.12 \mathrm{a}$ & $5.42 \mathrm{a}$ & $1.21 \mathrm{a}$ & $1.28 \mathrm{ab}$ & $18.10 \mathrm{ab}$ & $19.17 \mathrm{a}$ \\
\hline
\end{tabular}

*Values having a common alphabetical letter (s), do not significantly differ, using the revised L.S.D. test at $\mathrm{P}=0.05$.

Table 5. The main effects of biofertilizer types and phosphorus fertilizer rates on dry seed yield of common bean plants during the seasons of 2004 and 2005

\begin{tabular}{|c|c|c|c|c|}
\hline \multirow[t]{2}{*}{ Treatments } & \multicolumn{2}{|c|}{ Seed index (g) } & \multicolumn{2}{|c|}{ Dry seed yield fed ${ }^{-1}(\mathrm{~kg})$} \\
\hline & 2004 & 2005 & 2004 & 2005 \\
\hline \multicolumn{5}{|l|}{ Biofertilizer typ } \\
\hline Phosphorin & $21.85 \mathrm{a}^{*}$ & $23.49 \mathrm{a}$ & $1127.93 \mathrm{~b}$ & $1305.98 \mathrm{~b}$ \\
\hline Mycorrhiza & $23.20 \mathrm{a}$ & $24.94 \mathrm{a}$ & 1279rr.a & $1443.98 \mathrm{a}$ \\
\hline \multicolumn{5}{|c|}{$\underline{P}$ rate $\left(k g P_{2} \underline{O}_{5} \underline{f e d}^{-1}\right)$} \\
\hline 0 & $17.01 \mathrm{c}$ & $19.10 \mathrm{c}$ & $555.99 \mathrm{c}$ & $693.32 \mathrm{~d}$ \\
\hline
\end{tabular}




\begin{tabular}{ccccc}
\hline 30 & $21.94 \mathrm{~b}$ & $23.71 \mathrm{~b}$ & $1260.65 \mathrm{~b}$ & $1381.98 \mathrm{c}$ \\
60 & $25.64 \mathrm{a}$ & $27.64 \mathrm{a}$ & $1527.98 \mathrm{a}$ & $1781.98 \mathrm{a}$ \\
90 & $25.51 \mathrm{ab}$ & $26.42 \mathrm{ab}$ & $1469.21 \mathrm{a}$ & $1642.65 \mathrm{~b}$ \\
\hline
\end{tabular}

*Values having a common alphabetical letter (s), do not significantly differ, using the revised L.S.D. test at $\mathrm{P}=0.05$.

Interaction Effect of Phosphorous and Biofertilizers on Dry Seeds Yield and its Components:

Table (6 and 7) showed the interaction effect of biofertilizer inoculation and P- rates on dry seed yield and its components. Generally, there were significant effects of the interaction, in both seasons on number of dry pod plant ${ }^{-1}$, seed index, dry seed yield $\mathrm{fed}^{-1}$, number of dry seeds pod ${ }^{-1}$ and dry seeds weight pod $^{-1}$.

It is notable that the plants received $\mathrm{P}$ at 60 or $90 \mathrm{~kg}$ $\mathrm{P}_{2} \mathrm{O}_{5} \mathrm{fed}^{-1}$ and inoculated with Mycorrhiza and Phosphorein produced higher mean value than control in both seasons . It was clear also that plants fertilized with $60 \mathrm{~kg} \mathrm{P}_{2} \mathrm{O}_{5} \mathrm{fed}^{-1}$ in the presence of Mycorrhiza almost gave the highest values of seed index and dry seeds pod $^{-1}$ in both seasons while the highest values of dry seed yield fed $^{-1}$ was noticed only in the second season. This is in coincidence with the findings of Negeve and Roncadori (1985) who indicated that phosphate fertilization was more effective in stimulating growth and yield of sweet potato in the presence of VAM- fungi.

\section{Effects of the biofertilizer types on Chemical} Contents of Dry seeds:

Table (8) showed that the influence of seed inoculation with Phosphorin or Mycorrhiza on N, P, K and protein contents in dry seeds were not significant, in both seasons. El Sharawy et al. (1995) found a similar trend for VAM, PDB added as solely and dual inoculation with barley plants.

\section{Effect of Phosphorus on Chemical Contents of Dry} Seeds

Tables (8) indicated clearly that increasing the applied $\mathrm{P}$ levels up to $60 \mathrm{Kg}_{2} \mathrm{O}_{5}$ fed $^{-1}$ consequently and significantly, increased $\mathrm{N}, \mathrm{P}$, and protein contents of dry seeds over that of the control treatment, in the two seasons. Increasing the applied $\mathrm{P}$ level to $90 \mathrm{P}_{2} \mathrm{O}_{5} \mathrm{fed}^{-1}$ was not associated with sufficient increments on the aforementioned chemical contents of dry seeds. On the other hand the four applied P levels did not significantly differ in their effects on dry seeds contents of $\mathrm{K}$, in the two growing seasons.

The stimulative effect of $\mathrm{P}$ on $\mathrm{N}$ and $\mathrm{P}$ contents dry seeds may be attributed to the high amount of available phosphorous and/ or the increase in absorbing efficiency of plant roots. Dawa et al.(2003) and Sarg (2004) found that phosphorus contents in pea shoots increased with increasing the level of applied phosphorus fertilizer. Also abdalla (2002) found that N, protein, $\mathrm{P}$ and $\mathrm{K}$ contents of faba bean leaves were increased by increasing P level from (100 to $200 \mathrm{k} \mathrm{g}$ ) super phosphate fed $^{-1}$.

Table 6. The interaction effects of biofertilizer types and phosphours fertilizer rates on dry seed yield and its components of common bean plants during the seasons of 2004 and 2005

\begin{tabular}{|c|c|c|c|c|}
\hline$P$ rate $\left(\mathrm{kg} \mathrm{P}_{2} \mathrm{O}_{5}\right.$ fed $\left.^{-1}\right)$ & \multicolumn{2}{|c|}{2004} & \multicolumn{2}{|c|}{2005} \\
\hline \multicolumn{5}{|c|}{ No. of dry seeds pod } \\
\hline & Phosphorein & Mycorrhiza & Phosphorein & Mycorrhiza \\
\hline 0 & $3.60 \mathrm{c}^{*}$ & $3.80 \mathrm{c}$ & $4.05 \mathrm{~d}$ & $4.20 \mathrm{~d}$ \\
\hline 30 & $4.55 \mathrm{~b}$ & $4.60 \mathrm{~b}$ & $4.70 \mathrm{~cd}$ & $4.80 \mathrm{~cd}$ \\
\hline 60 & $4.75 \mathrm{ab}$ & $5.30 \mathrm{a}$ & $5.20 \mathrm{abc}$ & $5.95 \mathrm{a}$ \\
\hline 90 & $4.90 \mathrm{ab}$ & $5.35 \mathrm{a}$ & $5.10 \mathrm{bc}$ & $5.75 \mathrm{ab}$ \\
\hline \multicolumn{5}{|c|}{ Weight of dry seeds pod ${ }^{-1}$} \\
\hline & Phosphorein & Mycorrhiza & Phosphorein & Mycorrhiza \\
\hline 0 & $0.85 \mathrm{c}$ & $0.92 \mathrm{bc}$ & $0.98 \mathrm{c}$ & $1.03 \mathrm{bc}$ \\
\hline 30 & $1.11 \mathrm{ab}$ & $1.17 \mathrm{a}$ & $1.17 \mathrm{abc}$ & $1.24 \mathrm{ab}$ \\
\hline 60 & $1.21 \mathrm{a}$ & $1.20 \mathrm{a}$ & $1.36 \mathrm{a}$ & $1.31 \mathrm{a}$ \\
\hline 90 & $1.19 \mathrm{a}$ & $1.23 \mathrm{a}$ & $1.28 \mathrm{a}$ & $1.29 \mathrm{a}$ \\
\hline \multicolumn{5}{|c|}{ No. of dry pods plant ${ }^{-1}$} \\
\hline & Phosphorein & Mycorrhiza & Phosphorein & Mycorrhiza \\
\hline
\end{tabular}




\begin{tabular}{ccccc}
\hline 0 & $8.60 \mathrm{c}$ & $9.95 \mathrm{c}$ & $9.85 \mathrm{~b}$ & $10.95 \mathrm{~b}$ \\
30 & $15.15 \mathrm{~b}$ & $17.85 \mathrm{ab}$ & $16.95 \mathrm{a}$ & $18.20 \mathrm{a}$ \\
60 & $18.45 \mathrm{a}$ & $19.35 \mathrm{a}$ & $19.25 \mathrm{a}$ & $20.90 \mathrm{a}$ \\
90 & $17.50 \mathrm{ab}$ & $18.70 \mathrm{a}$ & $18.35 \mathrm{a}$ & $20.00 \mathrm{a}$ \\
\hline
\end{tabular}

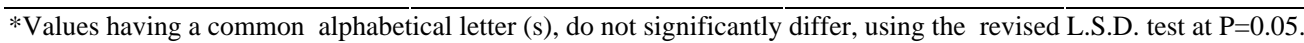

Table 7. The interaction effects of biofertilizer types and phosphours fertilizer rates on dry seed yield and its components of common bean plants during the seasons of 2004 and 2005

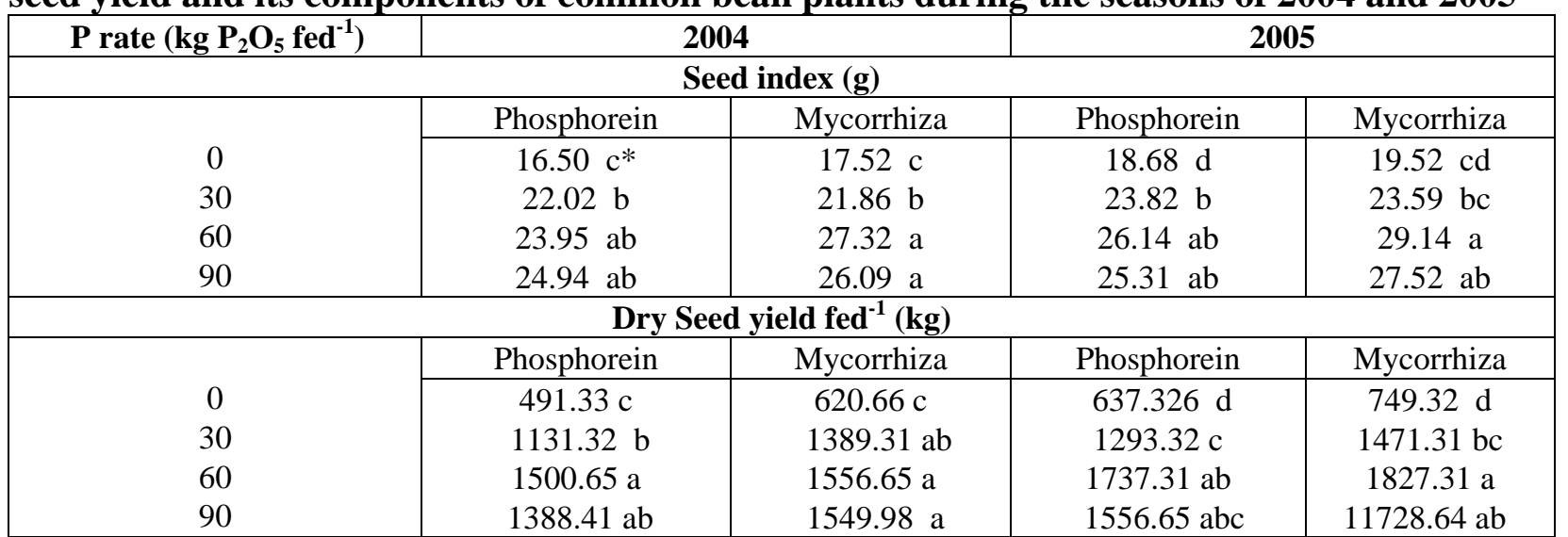

*Values having a common alphabetical letter (s), do not significantly differ, using the revised L.S.D. test at $\mathrm{P}=0.05$.

Table 8. The main effects of biofertilizer types and phosphorus fertilizer rates on the chemical constituent of dry seeds of common bean plants during the seasons of 2004 and 2005

\begin{tabular}{|c|c|c|c|c|c|c|c|c|c|}
\hline \multirow[t]{2}{*}{ Treatments } & \multicolumn{2}{|c|}{$\mathbf{N}(\%)$} & \multicolumn{2}{|c|}{$\mathbf{P}(\%)$} & \multicolumn{2}{|c|}{$\mathrm{K}(\%)$} & \multicolumn{3}{|c|}{ Protein $(\%)$} \\
\hline & 2004 & 2005 & 2004 & 2005 & 2004 & 2005 & 2004 & & 2005 \\
\hline \multicolumn{10}{|c|}{ Biofertilizer type } \\
\hline Phosphorin & $3.61 \mathrm{a}^{*}$ & $3.70 \mathrm{a}$ & $0.46 \mathrm{a}$ & $0.47 \mathrm{a}$ & 2.35 & 2.42 & 22.47 & & $23.15 \mathrm{a}$ \\
\hline Mycorrhiza & $3.84 \mathrm{a}$ & $3.95 \mathrm{a}$ & $0.47 \mathrm{a}$ & $0.49 \mathrm{a}$ & 2.38 & $2.41 \mathrm{a}$ & 23.99 & & $24.71 \mathrm{a}$ \\
\hline \multicolumn{10}{|c|}{$\underline{P}$ rate $\left(\mathrm{kg}^{\mathrm{P}} \underline{\mathrm{O}}_{5} \underline{\mathrm{fed}}^{-1}\right)$} \\
\hline 0 & $3.14 \mathrm{~b}$ & $3.19 \mathrm{~b}$ & $0.28 \mathrm{c}$ & $0.29 \mathrm{c}$ & 2.24 & 2.30 & 19.41 & & $19.95 \mathrm{~b}$ \\
\hline 30 & $3.38 \mathrm{~b}$ & $3.46 \mathrm{~b}$ & $0.44 \mathrm{~b}$ & $0.45 \mathrm{~b}$ & 2.30 & 2.36 & 21.13 & $b$ & $21.62 \mathrm{~b}$ \\
\hline 60 & $4.27 \mathrm{a}$ & $4.37 \mathrm{a}$ & $0.58 \mathrm{a}$ & $0.60 \mathrm{a}$ & 2.48 & 2.53 & 26.70 & $\mathrm{a}$ & $27.33 \mathrm{a}$ \\
\hline 90 & $4.11 \mathrm{a}$ & $4.29 \mathrm{a}$ & $0.56 \mathrm{a}$ & $0.58 \mathrm{a}$ & 2.44 & 2.47 & 25.69 & $\mathrm{a}$ & $26.81 \mathrm{a}$ \\
\hline
\end{tabular}

*Values having a common alphabetical letter (s), do not significantly differ, using the revised L.S.D. test at $\mathrm{P}=0.05$.

Interaction Effects of Phosphorus and Biofertilizers on Nutrients Contents of Dry Seeds

The results of the interaction effects of biofertilizer types and $\mathrm{P}$ fertilizer rates (Table 9) showed that the interaction had significant effect on the percentage of $\mathrm{N}$ and $\mathrm{P}$ and seed protein content in dry seeds in both seasons. However, $\mathrm{K}$ content in seeds did not significantly differ. Table (7) showed that the plants received $\mathrm{P}$ at 60 or $90 \mathrm{~kg} \mathrm{P}_{2} \mathrm{O}_{5} \mathrm{fed}^{-1}$ and inoculated with Mycorrhiza or Phosphorein produced higher mean value than control in both seasons. It was clear also that plants fertilized with $60 \mathrm{~kg} \mathrm{P}_{2} \mathrm{O}_{5} \mathrm{fed}^{-1}$ in the presence of Mycorrhiza the highest values of dry seeds protein content was noticed only in the first season. These results are in agreement with those reported by Gendiah
(1999) who found that Mycorrhiza fungus increased N and $\mathrm{P}$ contents in tomato leaves, as well as $\mathrm{P}$ content in roots. Nutrient contents and up-take with PDB inoculation was lower than mycorrhizal inoculation ,This indicates the importance of VAM for improving of adsorption and accumulation of elements in higher plants.

\section{Polynomial Quadratic Models.}

Bean dry seed yield responded positively to $\mathrm{P}$ fertilizer application rate and both biofertilizer types. The response to phosphorous was expressed by polynomial quadratic equation:

$\mathrm{Y}_{\mathrm{i}}=\mathrm{B}_{\mathrm{o}}+\mathrm{B}_{1} \mathrm{X}_{\mathrm{i}}+\mathrm{B}_{2} \mathrm{X}^{2}{ }_{\mathrm{i}}$

Where $Y_{i}$ is the predicted yield corresponding to nutrient rate $\mathrm{x}_{\mathrm{i}}$, 
$B_{0}$ is the intercept, represents the yield without $P$ fertilizer application, $\mathrm{B}_{1}$ and $\mathrm{B}_{2}$ are the linear and quadratic coefficients respectively and $\mathrm{X}$ is the level of $\mathrm{P}$ applied.

Four equations were established using the least squares methods described in Snedecor and Cochran (1989), to express the response of bean dry seeds yield to $\mathrm{P}$ fertilizer and two biofertilizer types for each season. (Table 10 and Fig. 1).

Seed yield was quadratically related to $P$ rate in the two seasons studied. The experimental yield values and the corresponding calculated values (predicted yield) from equations 2-5 (Table11) have shown highly significant values of correlation coefficients,

The Maximum Rate of $\mathbf{P}$ Fertilizer Application $\left(\mathbf{P}_{\text {max }}\right.$ ):

The maximum rates of $\mathrm{P}$ fertilizer applied $\left(\mathrm{P}_{\max }\right.$. ) at each biofertilizer type was calculated by differentiating " $Y$ " in eqs. 2-5 with regard to " $\mathrm{x}$ " (dy/dx) and equating $\mathrm{dy} / \mathrm{dx}=0$, then $\mathrm{dy} / \mathrm{dx}=\mathrm{B}_{1+} 2 \mathrm{~B}_{2} \mathrm{x}$

$$
\mathrm{P}_{\max }=\mathrm{B} 1 / 2 \mathrm{~B}_{2}
$$

$\mathrm{P}_{\max }$, is the level of fertilizer $\mathrm{P}$ for the maximum yield, was used to calculate maximum yield $\mathrm{Y}_{\max }$ for each biofertilizer in both season. $\mathrm{P}_{\max }$ were found 69.46, 67.53, 67.96 and $69.07 \mathrm{~kg} \mathrm{P}_{2} \mathrm{O}_{5} / \mathrm{fed}$. while the maximum yield were $1487.84,1637.03,1690.13$ and $1832.61 \mathrm{~kg} /$ fed. for Phosphorein 2004,Mycorrhiza2004 Phosphorein 2005and Mycorrhiza2005 respectively. Data indicated that Mycorrhiza inoculation could have maximum yield (Ymax) of1637.03 and $1832.61 \mathrm{~kg} / \mathrm{fed}$. If maximum

levels of P fertilization of 67.53 and $69.07 \mathrm{~kg} / \mathrm{fed}$. were applied in 2004 and 2005 seasons respectively, whereas Phosphorein would need 69.46 and $67.96 \mathrm{~kg} / \mathrm{fed}$. of $\mathrm{P}$ fertilizer to reach the maximum yield of 1487.84 and $1690.13 \mathrm{~kg} / \mathrm{fed}$. in 2004 and 2005 seasons respectively.

\section{Net Return of Maximum P Level.}

Net returns from maximum yields of bean dry seeds, as a result of receiving maximum levels of $\mathrm{P}$ fertilizer in two seasons were calculated and presented in Table (12). In calculations, it is assumed that the local price of $15 \mathrm{~kg} \mathrm{P}_{2} \mathrm{O}_{5}$ fertilizer was 100 Egyptian pound,

Table 9. The interaction effects of biofertilizer types and phosphorus fertilizer rates on the chemical constituent of common bean plants seeds during the seasons of 2004 and 2005

\begin{tabular}{|c|c|c|c|c|}
\hline P rate $\left(\mathrm{kg} \mathrm{P}_{2} \mathrm{O}_{5} \mathrm{ha}^{-1}\right)$ & \multicolumn{2}{|c|}{2004} & \multicolumn{2}{|c|}{2005} \\
\hline \multicolumn{5}{|c|}{$\mathbf{N \%}$} \\
\hline & Phosphorein & Mycorrhiza & Phosphorein & Mycorrhiza \\
\hline 0 & $3.12 \mathrm{c}^{*}$ & $3.16 \mathrm{c}$ & $3.18 \mathrm{c}$ & $3.20 \mathrm{c}$ \\
\hline 72 & $3.36 \mathrm{bc}$ & $3.40 \mathrm{bc}$ & $3.44 \mathrm{bc}$ & $3.48 \mathrm{bc}$ \\
\hline 144 & $4.09 \mathrm{a}$ & $4.45 \mathrm{a}$ & $4.15 \mathrm{a}$ & $4.59 \mathrm{a}$ \\
\hline 216 & $3.88 \mathrm{ab}$ & $4.34 \mathrm{a}$ & $4.04 \mathrm{ab}$ & $4.54 \mathrm{a}$ \\
\hline \multicolumn{5}{|c|}{$\mathrm{P} \%$} \\
\hline & Phosphorein & Mycorrhiza & Phosphorein & Mycorrhiza \\
\hline 0 & $0.27 \mathrm{c}$ & $0.28 \mathrm{c}$ & $0.29 \mathrm{~d}$ & $0.30 \mathrm{~d}$ \\
\hline 72 & $0.43 \mathrm{~b}$ & $0.44 \mathrm{~b}$ & $0.44 \mathrm{c}$ & $0.46 \mathrm{bc}$ \\
\hline 144 & $0.57 \mathrm{a}$ & $0.59 \mathrm{a}$ & $0.59 \mathrm{a}$ & $0.60 \mathrm{a}$ \\
\hline 216 & $0.56 \mathrm{a}$ & $0.57 \mathrm{a}$ & $0.57 \mathrm{ab}$ & $0.59 \mathrm{a}$ \\
\hline \multicolumn{5}{|c|}{$\mathrm{K} \%$} \\
\hline & Phosphorein & Mycorrhiza & Phosphorein & Mycorrhiza \\
\hline 0 & 2.24 & 2.26 & 2.29 & 2.31 \\
\hline 72 & 2.29 & 2.31 & 2.37 & 2.35 \\
\hline 144 & 2.47 & 2.50 & 2.52 & 2.53 \\
\hline 216 & 2.42 & 2.46 & 2.49 & 2.46 \\
\hline \multicolumn{5}{|c|}{ Protein (\%) } \\
\hline & Phosphorein & Mycorrhiza & Phosphorein & Mycorrhiza \\
\hline 0 & $19.07 \mathrm{c}$ & $19.74 \mathrm{c}$ & $19.90 \mathrm{c}$ & $20.01 \mathrm{c}$ \\
\hline 72 & $21.01 \mathrm{bc}$ & $21.24 \mathrm{bc}$ & $21.51 \mathrm{bc}$ & 21.74 bc \\
\hline 144 & $25.56 \mathrm{a}$ & 27.84 a & $25.95 \mathrm{a}$ & $28.71 \mathrm{a}$ \\
\hline 216 & $24.24 \mathrm{ab}$ & $27.13 \mathrm{a}$ & $25.25 \mathrm{ab}$ & $28.38 \mathrm{a}$ \\
\hline
\end{tabular}

*Values having a common alphabetical letter (s), do not significantly differ, using the revised L.S.D. test at $\mathrm{P}=0.05$.

Table 10. The polynomial quadratic equations expressing beans dry seed yields as affected by $\mathbf{P}$ fertilization and two types of biofertilizers inoculation in the two seasons

Treatment Polynomial Quadratic Equations




\begin{tabular}{ll}
\hline Phosphorein 2004 & Y1 $=-0.2087 \mathrm{x}^{2}+28.994 \mathrm{x}+\lfloor\wedge \cdot .83(2)$ \\
Micorrhiza 2004 & $\mathrm{Y} 2=-0.2179 \mathrm{x}^{2}+29.429 \mathrm{x}+643.38(3)$ \\
& $\mathrm{Y} 3=-0.2324 \mathrm{x}^{2}+31.589 \mathrm{x}+616.7(4)$ \\
Phosphorein 2005 & $\mathrm{Y} 4=-0.228 \mathrm{x}^{2}+31.496 \mathrm{x}+744.89(5)$ \\
Micorrhiza 2005 & P
\end{tabular}

Table 11. Experimental and predicted seed yield of bean as affected by rates of $P$ application and biofertilizer types in 2004 and 2005 seasons

\begin{tabular}{|c|c|c|c|c|c|c|c|}
\hline \multicolumn{7}{|c|}{ Season 2004} & \multirow[b]{3}{*}{ Pre } \\
\hline \multicolumn{2}{|c|}{ Yield (kg/fed.) } & & & \multicolumn{2}{|c|}{ Yield (kg/fed.) } & & \\
\hline Treatments & & Exp & Pre & Treatments & & Exp & \\
\hline \multirow{4}{*}{ Phosphorein } & P0 & 491.33 & 480.83 & \multirow{4}{*}{ Mycorrhiza } & $\mathrm{P} 0$ & 620.66 & 643.38 \\
\hline & $\mathrm{P}_{30}$ & 1131.32 & 1162.82 & & $\mathrm{P}_{30}$ & 1389.31 & 1330.14 \\
\hline & $\mathrm{P}_{60}$ & 1500.65 & 1469.15 & & $\mathrm{P}_{60}$ & 1556.65 & 1624.68 \\
\hline & $\mathrm{P}_{90}$ & 1389.31 & 1399.82 & & $\mathrm{P}_{90}$ & 1549.98 & 1527 \\
\hline \multirow{2}{*}{\multicolumn{2}{|c|}{$\mathrm{R}=0.9981$}} & & & \multicolumn{3}{|l|}{$\mathrm{R}=0.9922$} & \\
\hline & & & Season 200 & & & & \\
\hline \multicolumn{2}{|c|}{ Yield (kg/fed.) } & & & \multicolumn{2}{|c|}{ Yield (kg/fed.) } & & \\
\hline \multicolumn{2}{|l|}{ Treatments } & $\begin{array}{l}\text { Ex } \\
\mathrm{p}\end{array}$ & Pre & Treatments & & Exp & Pre \\
\hline \multirow{4}{*}{ Phosphorein } & P0 & 637.326 & 616.7 & \multirow{4}{*}{ Mycorrhiza } & $\mathrm{P} 0$ & 749.32 & 744.89 \\
\hline & $\mathrm{P}_{30}$ & 1293.32 & 1355.21 & & $\mathrm{P}_{30}$ & 1471.31 & 1484.57 \\
\hline & $\mathrm{P}_{60}$ & 1737.31 & 1675.4 & & $\mathrm{P}_{60}$ & 1827.31 & 1813.85 \\
\hline & $\mathrm{P}_{90}$ & 1556.65 & 1577.27 & & $\mathrm{P}_{90}$ & 1728.64 & 1732.73 \\
\hline $\mathrm{R}=0.9938$ & & & & $\mathrm{R}=0.9997$ & & & \\
\hline
\end{tabular}

Table 12. Values of maximum rates of $P$ fertilizer, maximum yields and net returns of bean cultivar Bronco as affected by $P$ fertilization and Phosphorein and Mycorrhiza inoculation in 2004 and 2005 seasons

\begin{tabular}{|c|c|c|c|}
\hline Treatments Biofertilizer types & $\left(P_{\text {max. }}\right.$ fed. $\left.^{-1}\right)$ & $Y_{\max .}\left(\mathrm{kg} \mathrm{fed}^{-1}\right)$ & Net retun $(\mathrm{EP})$ \\
\hline Phosphorein 2004 & 69.46 & 1487.84 & 14415 \\
\hline Micorrhiza 2004 & 67.53 & 1637.03 & 15920 \\
\hline Phosphorein 2005 & 67.96 & 1690.13 & 16448 \\
\hline Micorrhiza 2005 & 69.07 & 1832.61 & 17866 \\
\hline
\end{tabular}

Price of $1 \mathrm{~kg}$ of peas dry seed $=10 \mathrm{EP}$.

$\mathrm{EP}=$ Egyptian Pound

Price of $\mathrm{P}$ fertilization $\left(15 \mathrm{~kg} \mathrm{P}_{2} \mathrm{O}_{5}\right)=100 \mathrm{EP}$. 


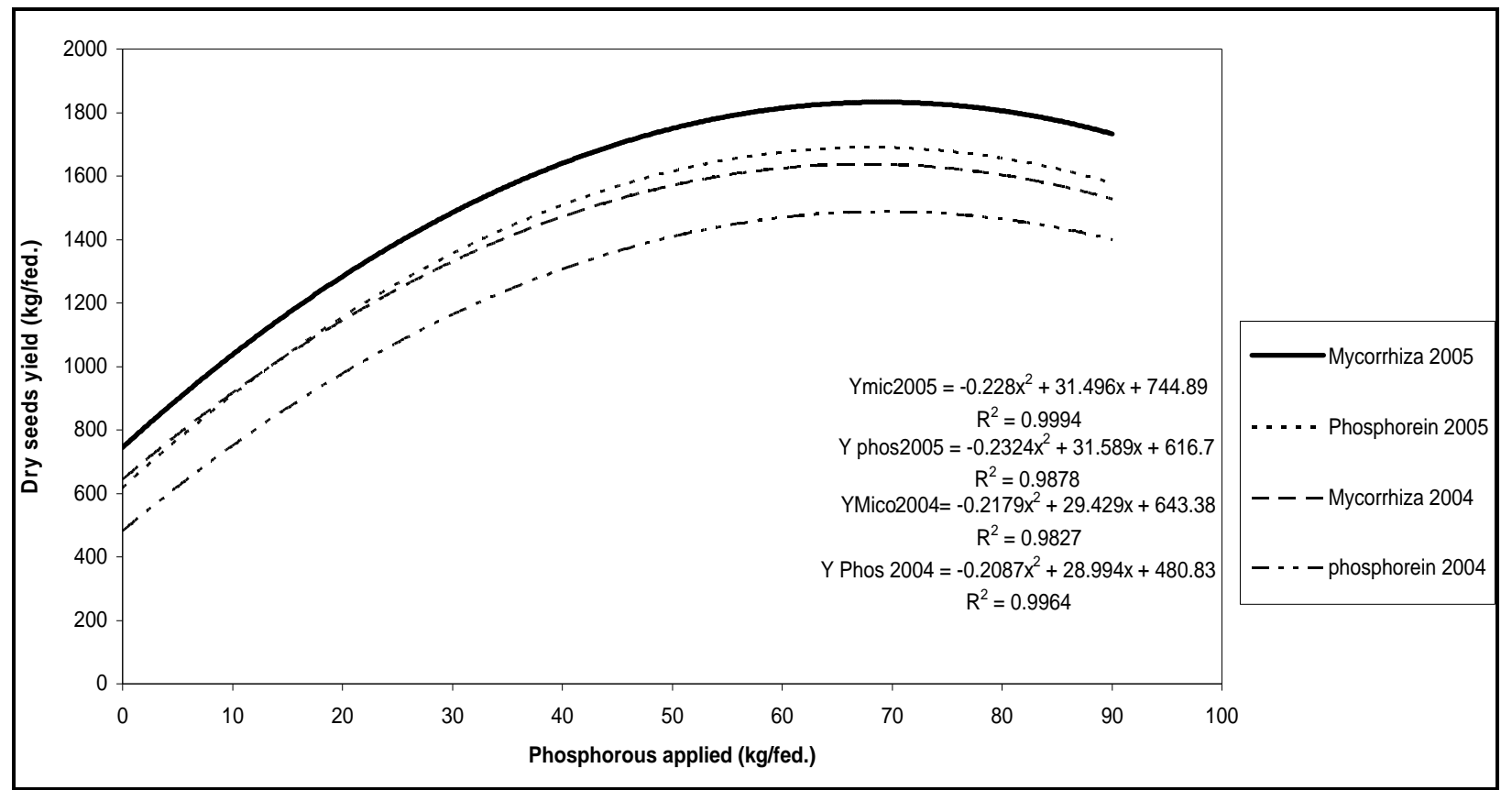

Fig 1. Dry seeds yield responce curve of bean as affected by inorganic phosphate application and Mycorrhiza and Phosphorein inoculation during 2004 and 2005 seasons

(EP) and the local price of $1 \mathrm{~kg}$ of bean seeds yield was $10 \mathrm{EP}$. The results indicated that, the net returns were 14415, 15920, 16448 and 17866 for Phosphorein 2004, Mycorrhiza2004, Phosphorein 2005and Mycorrhiza 2005 respectively. Thus, it is evident that net returns of Mycorrhiza were more effective than Phosphorein. These results are in agreement with those of Gendiah (1999).

\section{REFERENCES}

Abdalla A.M. (2002): Effect of bio - and mineral phosphorus Fertilizer on the growth, productivity and nutritional value of faba bean. Egypt. J. Hort., 29: 187203.

Bennink M.R. (2001): Global Importance of Common Bean. 'http://www.michiganbean.org/beanBag/beanBag.html.

Chapman H.D and Pratt P.F. (1978): Methods of Analysis for Soils, Plants and Waters. Division of Agriculture Sciences, University of California, Davis, pp 50.

Dawa K.E., Tartoura A.A., Darweesh M.A. (2003): Effect of phosphorus fertilization and some growth promoters on growth and yield pea (Pisum sativum L) J. Agric. Sci. Mansoura Univ., 28: 1327-1343.

El-Sharawy M.O., Abd El Moneim E.M., El Ghandour L.A. (1995): Influence of vesicular arbuscular mycorrhizal fungi and phosphate dissolving bacteria on growth, $\mathrm{P}$ and $\mathrm{Zn}$ contents of barley. J. Agric. Sci. Mansoura University, 20: 507-518
El-Kalla S.E., Mostafa A.K., Abd Allah A.A., Awad A.A. (1999): Mineral and Bio-phosphatic fertilization for intercropped faba bean and onion. Egypt. J. Agric. Res., 77:253-271

EL-Korashy M.A. (2003): Effect of vesicular arbuscular Mycorrhizal fungi and Rhizobium lupin in combination with N P K and fungicides in the control of damping off disease of pea nut plants- Minufiya J. Agric. Res . 28: $685-704$.

EL-Shimi A.A. (2003): Effect of some levels of phosphorus fertilization and Phosphorein biofertilizer on growth, yield and chemical composition of some sweet potato cultivars J. Agric .sci. Mansoura Univ .28:2889-2901.

Feleafel M.N., Sanaa M. (2001): Response of snap bean cultivars (Phaseolus vulgaris L.) to varying rates of nitrogen and phosphorus fertilization. J. Agric. Sci. Mansoura Univ., 26: 1735-1748.

Frank W.S. (2002): The phosphate uptake mechanism. Plant and Soil .245: 105-114

Gendiah H.M. (1999): Effect of biofertilization by using Mycorrhizal fungus and Rhizobium sp. bacteria on the growth and macro nutrients of Manzanillo olive seedlings. Ann. Agric. Sci. Moshtohor, 37 (1): 575-584.

Gupta S.C. (2004): Response of gram (Cicer arietinum) to types and methods of microbial inoculation. Ind. J. Agric. Sci. 74: 73-75.

Jackson M.L. (1967): Soil Chemical Analysis. Verlag. Prentia. Hall inc., Englewoud. Cliffs, USA. 
Ling E.R. (1963): Determination of total nitrogen by semimicro Kjeldahl method. Dairy Chem., 11: 23-84.

Maliha R., Khalil S., Ayub N., Alam S., Latif F. (2004): Organic acids production and phosphate solubilization by phosphate solubilizing microorganisms (PSM) under in vitro conditions. Pak. J. Biol. Sci.7: 187-196.

Negeve J.M., Roncadori R.W. (1985): The interaction of vasicular-arbuscular mycorrhizae and soil phosphorus fertility on growth of sweet potato (Ipomoea batatas). Field Crop Res., 12: 181-185.

Page A.L., Miller R.H., Keeney D.R. (1982): Methods of soil analysis, chemical and microbiological properties, part $2,2^{\text {nd }}$ ed. ASA-SSSA, Madison, Wisc., USA.

Sarg S.M.A. (2004): Influence of seed inoculation with phosphorein and levels of phosphorus fertilization on growth, mineral contents, seedless green pods yield and yield of seeds of three sugar pea cultivars under sandy soil conditions. J. Agric. Sci. Mansoura Univ., 29: 47294744.

SAS (1996): Software program. Cary, North Carolina State Univ., Karl M Glsener. USA.
Sattar M.A., Gaur A.C. (1987): Production of auxins and gibberellins by phosphate dissolving microorganisms. Zbl. Microbial., 142, 393-395.

Shafeek M., Al Aisha F., Ali H. (2004): The productivity of broad bean plant as affected by chemical and /or natural phosphorus with different biofertilizer. J. Agric. sci. Mansoura Univ., 29 (5): 2727-2740.

Smith S.E., Read D.J. (1997): Mycorrhizal Symbiosis. Academic Press, London.

Snedecor G.W., Cochran W.G. (1989): Statistical Methods. Iowa State University Press, Ames, Iowa.

Zaidi A., Khan M.S., Amil M. (2003): Interactive effect of rhizotrophic microorganisms on yield and nutrient uptake of chickpea (Cicer arirtinum L.), Eur. J. Agron. 19: $15-21$

Zaidi A., Khan M.S., Amil M. (2004): Bioassociative effect of rhizospheric microorganisms on growth, yield and nutrient uptake of green gram. J. Plant Nutr. 27: 599610. 


\section{الملخص العربي}

\section{التأثيرات الناجه عن كل من فطر الميكوريزا و البكتيريا المذيبة للفوسفات على نباتات الفاصوليا وقدرةا على زيادة نمو النباتات وانتاج البذور}

$$
\text { حسن احمد الخطيب، سعيد محمد جبر، فتحى ابراهيم رضوان، رباب فاروق ابو العلى }
$$

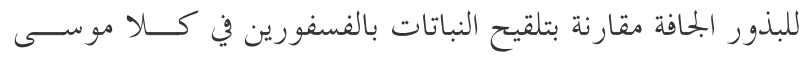
الزراعة وقد أظهرت الدراسة ان افضل المعاملات التداخلية في كلا موسمي الزراعة كانت تلقيح بذور الفاصوليا بأى من نوعى الـسماد

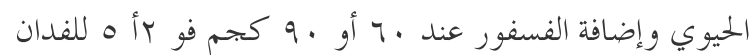
تم تمثيل نتائج إنتاجية المحصول الجاف للفاصولبا بأربع معادلات


داله للتسميد الفوسفاتى والحيوي. وقد استخدمت ثوابت المعادلات

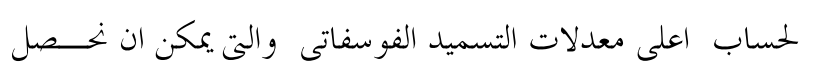
منها على اعلى انتاجية من محصول البذرة.
اجريت هذه الدراسة خلال موسمى ع ...T، ه . .بأف مزرعة كلية الزراعة بدمنهور في منطقة البستان بمحافظة البحيرة، جمهورية مصر العربية همدف اختبار التأثيرات الرئيسية لتلقيح البذور بنـــوعين

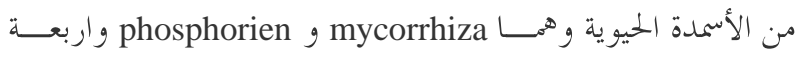

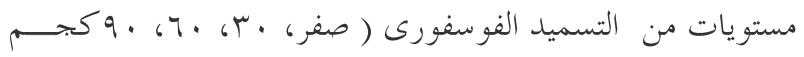
فو بأه للفدان) و التداخلات على صفات النمو والمصصول الكلـى ليى للبذور الجافة ومكوناته و كذلك بعض التحليلات الكيماوية للبذور الجافة للفاصوليا صنف برونكو.وقد اوضحت النتائج ان أدى تلقيح

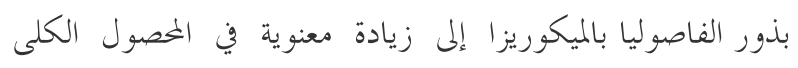

